(c) American Dairy Science Association, 2004.

\title{
Relative Acidifying Activity of Anionic Salts Commonly Used to Prevent Milk Fever
}

\author{
J. P. Goff, R. Ruiz, ${ }^{\star}$ and R. L. Horst \\ Metabolic Diseases and Immunology Unit, \\ National Animal Disease Center, \\ USDA-Agricultural Research Service, Ames, IA 50010
}

\section{ABSTRACT}

High cation diets can cause milk fever in dairy cows as they induce a metabolic alkalosis reducing the ability of the cow to maintain calcium homeostasis at the onset of lactation. Adding anions to the diet can offset the effect of the high cation forages by inducing a mild metabolic acidosis, restoring the ability to maintain calcium homeostasis. The difference in $\mathrm{mEq}$ of dietary cations and anions (DCAD) is most often expressed as $\left(\mathrm{Na}^{+}+\mathrm{K}^{+}\right)-\left(\mathrm{Cl}^{-}+\mathrm{S}^{--}\right)$. This equation implies that a $\mathrm{mEq}$ of chloride and a $\mathrm{mEq}$ of sulfate are equipotent in their ability to alter acid-base balance of the cow. Using blood and urine $\mathrm{pH}$ to monitor effects on acidbase balance, experiments were conducted to test the relative acidifying activity of various sulfate and chloride anion sources in nonpregnant, nonlactating Jersey cows. Across all experiments, chloride proved to have about 1.6 times the acidifying activity of sulfate. Calcium and magnesium, ignored by the common DCAD equation, had a small but significant alkalinizing effect when accompanying chloride or sulfate. The ranking of the anion sources tested at a dose of $2 \mathrm{Eq} /$ $\mathrm{d}$, from most to least potent urine acidifier, was hydrochloric acid, ammonium chloride, calcium chloride, calcium sulfate, magnesium sulfate, and sulfur. These data should allow more accurate prediction of the response of late gestation cows to dietary cation-anion manipulation.

(Key words: milk fever, anionic salts, chloride, sulfate)

Abbreviation key: DCAD = dietary cation-anion difference, $\mathbf{S B E}=$ standard base excess.

\section{INTRODUCTION}

Parathyroid hormone initiates bone calcium resorption and renal production of 1,25-dihydroxyvitamin D

Received May 6, 2003.

Accepted October 6, 2003.

Corresponding author: J. P. Goff; e-mail:jgoff@nadc.ars.usda.gov.

* Rodrigo Ruiz current address is: Elanco Animal Health, División de Eli Lilly, Av. Prol. Americas N ${ }^{\circ} 1592$ Piso 1, Col. Country Club, 44620 Guadalajara, Jalisco, Mexico. to permit calcium homeostasis in the recently calved cow. Cows fed diets high in cations, especially potassium and sodium, before calving are at increased risk of developing hypocalcemia and milk fever (Ender et al., 1971; Goff and Horst, 1997). Diets high in cations cause blood $\mathrm{pH}$ to increase, resulting in a state of mild metabolic alkalosis. We have previously presented indirect evidence that metabolic alkalosis reduces tissue responsiveness to parathyroid hormone. Cows fed diets high in cations have a reduced ability to mobilize bone calcium (Block, 1984; Goff et al., 1991) and reduced ability to produce the hormonal form of vitamin D, 1,25-dihydroxyvitamin D (Gaynor et al., 1989; Goff et al., 1989; Phillippo et al., 1994). Rat bone cell cultures provide more direct evidence that metabolic alkalosis reduces the efflux of calcium from bone (Bushinsky, 1996). The addition of anions to prepartal rations of dairy cows is a proven means of reducing dietary cation-anion difference, which reduces the incidence of milk fever (Dishington, 1975; Block, 1984; Oetzel et al., 1988). As dietary cation-anion difference declines, blood $\mathrm{pH}$ decreases and calcium homeostasis improves. Monitoring changes in urine $\mathrm{pH}$ as an index of body acid-base status has proved a valuable and inexpensive means of monitoring the success of addition of anions to prepartal rations to prevent milk fever in the field (Gaynor et al., 1989; Davidson et al., 1995; Jardon, 1995). Earlier studies suggest that acidification following addition of anionic salts to the ration is rapid-generally less than $36 \mathrm{~h}$. It also takes less than $36 \mathrm{~h}$ to realkalinize a cow once anionic salts are removed from the diet (Goff and Horst, 1998). A number of compounds are fed to cows as "anionic salts" for their ability to acidify the cow. However, they may not all have the same acidifying activity (Oetzel et al., 1991). The purpose of this study was to compare the relative acidifying activity of various doses of some of the anions commonly used for prevention of milk fever. In experiment 1 of this study, various anion sources were fed at one standard dose to each cow in the experiment. Trials of the second experiment compared acidifying activity of calcium chloride $\left(\mathrm{CaCl}_{2}\right)$ vs. calcium sulfate $\left(\mathrm{CaSO}_{4}\right)$, magnesium chloride $\left(\mathrm{MgCl}_{2}\right)$ vs. mag- 
nesium sulfate $\left(\mathrm{MgSO}_{4}\right)$, and hydrochloric acid $(\mathrm{HCl})$ vs. sulfuric acid $\left(\mathrm{H}_{2} \mathrm{SO}_{4}\right)$ at 3 graded doses. Because the type of diet fed to the cows might have an influence on the acidifying activity of the anion source, the second experiment was replicated using both alfalfabased (high endogenous cations and high protein) and corn silage-based (low endogenous cations and low protein) diets.

\section{MATERIALS AND METHODS}

\section{Anion Sources}

All sources of anions used in these studies were food or reagent grade and, with the exception of $\mathrm{HCl}$, and $\mathrm{CaSO}_{4}$, were at least $97 \%$ pure. Anhydrous $\mathrm{CaCl}_{2}$, hexahydrate $\mathrm{MgCl}_{2}$, heptahydrate $\mathrm{MgSO}_{4}$, elemental sulfur, and concentrated $\mathrm{H}_{2} \mathrm{SO}_{4}$ were from Mallinckrodt Chemical, Inc., St. Louis, MO; ammonium chloride $\left(\mathrm{NH}_{4} \mathrm{Cl}\right)$ from Fisher Scientific Co., Fairlawn, NJ: and dihydrated $\mathrm{CaSO}_{4}$ (85\% pure) was from United States Gypsum Co., Chicago, IL. The $\mathrm{HCl}$ used was 20 degree Baume or $31.45 \% \mathrm{HCl}$ by weight (W.M. Barr \& Co., Inc., Memphis, TN). Using these sources of anion, $1 \mathrm{Eq}$ of chloride was considered to be supplied by $73.5 \mathrm{~g}$ of anhydrous $\mathrm{CaCl}_{2}, 101 \mathrm{~g}$ of hexahydrate $\mathrm{MgCl}_{2}, 53.5 \mathrm{~g}$ of $\mathrm{NH}_{4} \mathrm{Cl}$, or $103 \mathrm{~mL}$ of $\mathrm{HCl}$. An Eq of sulfate was considered to be supplied by $123.2 \mathrm{~g}$ of heptahydrate $\mathrm{MgSO}_{4}, 16 \mathrm{~g}$ of elemental sulfur, $101 \mathrm{~g}$ of dihydrated $\mathrm{CaSO}_{4}$ or $28 \mathrm{~mL}$ of concentrated $\mathrm{H}_{2} \mathrm{SO}_{4}$.

\section{Experiment 1: Relative Urine Acidifying Activity of Hydrochloric Acid, Calcium Chloride, Ammonium Chloride, Magnesium Sulfate, Calcium Sulfate, and Elemental Sulfur}

Six mature nonpregnant, nonlactating Jersey cows were limit fed $5.8 \mathrm{~kg} \mathrm{DM} / \mathrm{d}$ of a corn silage-alfalfa based diet (Table 1) for $5 \mathrm{~d}$ to establish baseline urine $\mathrm{pH}$ values. Diets were limit fed to attempt to insure complete ingestion of the anion doses.

Each of the 6 cows was then fed diet supplemented with $2 \mathrm{Eq}$ of one of the 6 anion sources for 5 -d periods in a randomized crossover design. Treatment periods were separated by $3 \mathrm{~d}$ of feeding only basal ration. Half the ration was fed at $0800 \mathrm{~h}$ and the second half fed at $1500 \mathrm{~h}$. Cows were housed in individual box stalls bedded with wood shavings to prevent ingestion of bedding. Grab samples of midstream urine were collected between 1100 and $1145 \mathrm{~h}$ from each cow after eliciting micturition by manual stimulation of the vulva. Urine $\mathrm{pH}$ was determined within $60 \mathrm{~min}$ of collection (Corning $150 \mathrm{pH}$ meter, Corning, NY). Urine was collected from each cow on d 3, 4, and 5 of each treatment period, and the average of the urine $\mathrm{pH}$ values was used to determine the response of each cow to dietary treatment. The effect of anion source on urine $\mathrm{pH}$ was analyzed by analysis of variance followed by comparison of means by the method of least significant difference.

\section{Experiment 2. Effect of Chloride vs. Sulfate Sources at Graded Doses}

Each trial assessed the acidifying activity of a sulfate and chloride source that shared the same accompanying cation at 3 doses and utilizing one of 2 diets (alfalfa- or corn silage [with potassium carbonate]based diets). Seven nonlactating, nonpregnant Jersey cows, housed in a free-stall barn bedded with sand, were used in each trial. Each trial consisted of 7 periods, allowing each cow to receive each of 7 dietary treatments during the course of a trial in random order. Cows were limit fed basal ration $(5.3 \mathrm{~kg} \mathrm{DM} / \mathrm{d}$ of the alfalfa-based diet or $4.8 \mathrm{~kg} \mathrm{DM} / \mathrm{d}$ of the corn silage based diet) (Table 1) in 2 divided feedings (0800 and $2000 \mathrm{~h}$ for $10 \mathrm{~d}$ behind Calan gates (American Calan Inc, Northwood, NH) to which the cows were accustomed before hand. Then the appropriate anion supplement was added (one half the daily dose of anion suspended in $250 \mathrm{~mL}$ of water and mixed by hand into the morning and evening ration of each cow within the Calan gate tub) to the basal ration for the next 5 d. Two anion sources (a sulfate source and a chloride source sharing a common cation) were compared in each trial. The 2 anion sources compared in each trial were added to the diet at a rate of $0.75,1.5$, or 2.25 $\mathrm{Eq} / \mathrm{d}$. One treatment in each trial consisted of water only, for a total of 7 treatments/trial. At $3 \mathrm{~h}$ after the last feeding on $\mathrm{d} 5$ of each treatment period, jugular venous blood was collected anaerobically, and a midstream urine sample was obtained, eliciting micturition by manual stimulation of the vulva. Blood gases, hemoglobin, and $\mathrm{pH}$ were determined on whole heparinized samples of jugular venous blood maintained at $4^{\circ} \mathrm{C}$ until analyzed (within $1 \mathrm{~h}$ of obtaining the sample) (Nova Ultra-D Blood Gas Analyzer, Nova Biomedical, Waltham, MA). Standard base excess (SBE) was then calculated from measured blood $\mathrm{pH}$ and partial pressure of carbon dioxide, using an algorithm (Thomas, 1972). To use this algorithm, the default value for blood hemoglobin of $14.3 \mathrm{~g} / 100 \mathrm{~mL}$ whole blood was used. Not every cow has a blood hemoglobin concentration of $14.3 \mathrm{~g} / 100 \mathrm{~mL}$, but the blood hemoglobin concentration is relatively constant in individual cows. The equation utilized was: $\mathrm{SBE}=0.7998\left(\mathrm{HCO}_{3}{ }^{-}-24\right)+$ 28.149 (blood $\mathrm{pH}-7.4)$. The $\mathrm{SBE}$, which is generally positive in alkalosis and negative in acidosis, is defined as the amount of acid or base needed to restore $1 \mathrm{~L}$ of 
Table 1. Formulation and mineral composition of basal rations fed to Jersey cows in experiments 1 and 2. Cows were limit fed $5.8 \mathrm{~kg} \mathrm{DM} / \mathrm{d}$ in experiment 1 . In experiment 2 , the alfalfa-based diet was limit fed at $5.3 \mathrm{~kg} \mathrm{DM} / \mathrm{d}$ and the corn silage based diet was limit fed at $4.8 \mathrm{~kg} \mathrm{DM} / \mathrm{d}$.

\begin{tabular}{|c|c|c|c|}
\hline \multirow[b]{2}{*}{ Ingredient (\%DM) } & \multirow[b]{2}{*}{ Experiment 1} & \multicolumn{2}{|c|}{ Experiment 2} \\
\hline & & Alfalfa based & Corn silage based \\
\hline Alfalfa & 26.1 & 66.4 & \\
\hline Corn silage & 55.3 & & 96.9 \\
\hline Beet sugar pulp & 17.3 & 15.5 & \\
\hline Corn gluten feed & & 15.7 & \\
\hline Magnesium oxide & 0.3 & 0.4 & \\
\hline Limestone & & 1.6 & \\
\hline Potassium carbonate & & & 3.1 \\
\hline Vitamin-mineral mix ${ }^{1}$ & 0.6 & & \\
\hline Salt & 0.4 & 0.4 & \\
\hline \multicolumn{4}{|l|}{ Analysis (\%DM) } \\
\hline Calcium & 0.79 & 1.68 & 0.27 \\
\hline Phosphorus & 0.24 & 0.37 & 0.25 \\
\hline Magnesium & 0.39 & 0.58 & 0.16 \\
\hline Sodium & 0.22 & 0.26 & 0.06 \\
\hline Potassium & 1.47 & 2.01 & 2.92 \\
\hline Chloride & 0.59 & 0.73 & 0.28 \\
\hline Sulfur & 0.21 & 0.32 & 0.14 \\
\hline $\mathrm{CP}(\% \mathrm{DM})$ & 12.0 & 19.1 & 8.8 \\
\hline $\mathrm{DCAD}^{2}(\mathrm{mEq} / \mathrm{kg})$ & +175 & +222 & +610 \\
\hline 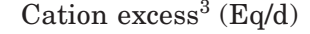 & 1.015 & 1.176 & 2.928 \\
\hline
\end{tabular}

${ }^{1}$ Vitamin-mineral premix supplied $12,500 \mathrm{IU}$ of retinyl palmitate, 2,500 IU of vitamin $\mathrm{D}_{3}, 30$ IU $\alpha$ tocopherol acetate, $0.11 \mathrm{mg}$ of Se and met or exceeded NRC requirements for all trace elements.

${ }^{2} \mathrm{DCAD}$ was defined as $\mathrm{mEq}(\mathrm{Na}+\mathrm{K})-(\mathrm{Cl}+\mathrm{S}) / \mathrm{kg} \mathrm{DM}$.

${ }^{3}$ Cation excess $-\mathrm{Eq} / \mathrm{d}$ of total cations $(\mathrm{Na}+\mathrm{K})$ in excess of total anions $(\mathrm{Cl}+\mathrm{S})$ fed to the cows each $\mathrm{d}$ in their basal rations. Treatments consisted of supplemental anions added to the basal ration in increments of $2 \mathrm{Eq} / \mathrm{d}$ in experiment 1 and $0.75,1.5$, or $2.25 \mathrm{Eq} / \mathrm{d}$ in experiment 2.

blood to "normal" acid-base composition $(\mathrm{pH}=7.40)$ at a partial pressure of carbon dioxide of $40 \mathrm{~mm}$ mercury in the blood. The algorithm used was developed using "normal" human blood parameters. The typical forage-based cow diet contains cations far in excess of anions. When these cations are absorbed from the intestinal tract, they increase plasma strong ion difference creating a metabolic alkalosis (Constable, 1999). Thus the bovine samples usually appear "alkaline" in relation to the "standard" human. Determinations of urine $\mathrm{pH}$ were made within $1 \mathrm{~h}$ of urine collection. In one trial (cows fed corn silage-based diet receiving graded doses of either $\mathrm{HCl}$ or $\mathrm{H}_{2} \mathrm{SO}_{4}$ ), urine titratable base content was assessed by placing $25 \mathrm{~mL}$ of urine into a beaker and slowly adding $0.10 \mathrm{~N} \mathrm{HCl}$ to the sample while stirring. The titratable base content was defined as the milliliter of acid required to acidify the urine sample to a $\mathrm{pH}$ of 4.5 .

Experimental treatment periods within each trial were separated by 5 -d rest periods in which the diet consisted of the basal ration only. Cows were also maintained on the basal ration during a 5- to 6 -wk rest time between trials.

The first 3 trials used the same 7 cows, and the basal ration was an alfalfa hay-based diet. In trials 4,5 , and 6 , seven different nonlactating Jersey cows were used, and the basal ration was a corn silage-based diet with added potassium bicarbonate (Table 1). In the first and fourth trials, the effects of $\mathrm{CaCl}_{2}$ and $\mathrm{CaSO}_{4}$ were assessed. In the second and fifth trials, the effects of $\mathrm{HCl}$ and $\mathrm{H}_{2} \mathrm{SO}_{4}$ were assessed. In the third and sixth trials, the effects of $\mathrm{MgCl}_{2}$ and $\mathrm{MgSO}_{4}$ were assessed.

\section{Statistical Analyses}

Urine $\mathrm{pH}$, blood $\mathrm{pH}$, and SBE data collected within each trial were analyzed by an initial analysis of variance using diet, anion source (including water), dose, and anion source $\times$ dose interaction as main effects (Statview 5.0, SAS Institute, Cary, NC). With diet included as a main effect in the ANOVA model, the effect of diet was not significant when comparing the effects of the chloride and sulfate salts of magnesium and calcium. Therefore, the data from trials 1 and 4, and data from trials 3 and 6 were combined to allow comparison of these anion sources across both diets. The effect of diet was significant in the comparison of $\mathrm{HCl}$ and $\mathrm{H}_{2} \mathrm{SO}_{4}$. Examination of these data suggested the diet difference was related to the higher urine and blood $\mathrm{pH}$ induced by the corn silage-based diet, which is apparent during the water treatment (zero anion) periods. Because the relative changes appeared to be 
similar, the data from trials 2 and 5 were also combined to allow comparison of these acids across both diets. Data from the combined trials were subjected to ANOVA with anion source (including water), dose, and anion source $\times$ dose interaction as main effects. Treatment means were compared to the mean obtained during water-only treatment, and also to the equal dose of the opposing anion by the method of least significant difference.

The data obtained from all 6 trials were also combined across all 3 anion sources and both diets for ANOVA where anion source (chloride, sulfate, or water), dose and anion source $\times$ dose interactions served as main effects. Treatment means were compared to the mean obtained during water-only treatment, and also to the equal dose of the opposing anion by the method of least significant difference.

In the final ANOVA, data were combined across all 3 doses, all 3 anion sources, and both diets were combined with anion (chloride, sulfate, or water) as the main effect. Treatment means were compared to the mean obtained during water-only treatment and to the opposing anion by the method of least significant difference.

\section{Animal Care and Use}

All procedures employed on the cows were approved by the Animal Care and Use Committee of the National Animal Disease Center.

\section{RESULTS}

\section{Experiment 1. Effect of Various Anion Sources Fed at One Dose}

Urine $\mathrm{pH}$ of cows when fed the basal ration only was $8.26 \pm 0.038$, which is referred to as baseline urine $\mathrm{pH}$. Urine $\mathrm{pH}$ values for cows fed basal ration plus $2 \mathrm{Eq}$ of elemental sulfur, $\mathrm{MgSO}_{4}, \mathrm{CaSO}_{4}, \mathrm{CaCl}_{2}, \mathrm{NH}_{4} \mathrm{Cl}$, or $\mathrm{HCl}$ are presented in Figure 1. Inclusion of elemental sulfur in the diet had no effect on urine $\mathrm{pH}$. Urine $\mathrm{pH}$ of cows fed diet with $\mathrm{MgSO}_{4}$ was $7.90 \pm 0.08$, which was not significantly different from baseline urine $\mathrm{pH}$ values. All other anion sources significantly reduced urine $\mathrm{pH}$ from baseline levels. Urine $\mathrm{pH}$ of cows fed diet with $\mathrm{HCl}(6.20 \pm 0.22)$ was significantly lower than the urine $\mathrm{pH}$ of cows fed the next strongest acidifying anions, $\mathrm{NH}_{4} \mathrm{Cl}(7.05 \pm 0.20)$ and $\mathrm{CaCl}_{2}(7.14 \pm 0.36)$. $\mathrm{NH}_{4} \mathrm{Cl}$ and $\mathrm{CaCl}_{2}$ were similar in acidifying activity. Both $\mathrm{CaCl}_{2}(P<0.08)$ and $\mathrm{NH}_{4} \mathrm{Cl}(P<0.04)$ were significantly stronger in urine acidifying activity than $\mathrm{CaSO}_{4}$ (urine $\mathrm{pH}=7.64 \pm 0.15$ ). Differences in urine acidifying activity between $\mathrm{CaSO}_{4}$ and $\mathrm{MgSO}_{4}$ were not statistically significant. Cows fed chloride salts

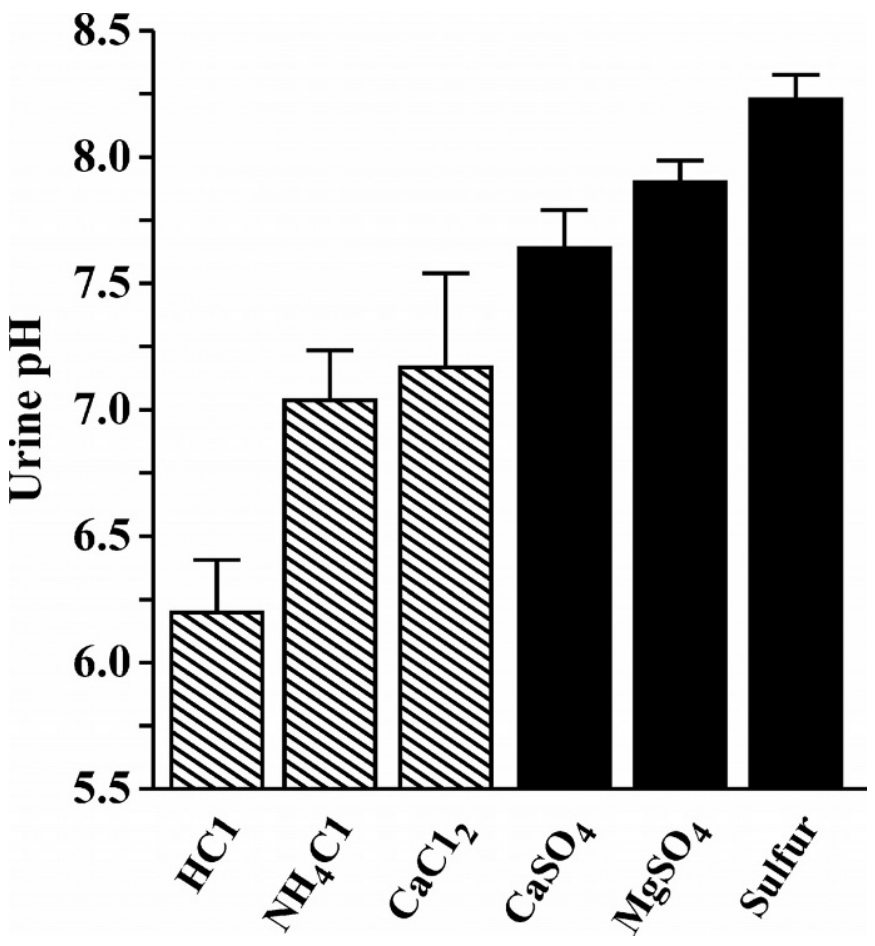

Figure 1. Mean \pm SEM urine $\mathrm{pH}$ of Jersey cows fed 2 Eq of anion using hydrochloric acid, ammonium chloride, calcium chloride, calcium sulfate, magnesium sulfate, or elemental sulfur as sources of anions. $(\mathrm{N}=6)$.

$\left(\mathrm{CaCl}_{2}\right.$ and $\mathrm{NH}_{4} \mathrm{Cl}$ treatment data combined) had significantly lower urine $\mathrm{pH}(P<0.01)$ than cows fed the sulfate salts $\left(\mathrm{MgSO}_{4}\right.$ and $\mathrm{CaSO}_{4}$ treatment data combined) $(7.10 \pm 0.20$ in chloride salt fed cows vs. $7.77 \pm 0.09$ in sulfate salt fed cows).

Cows fed the diet with added $\mathrm{MgSO}_{4}$ failed to consume the entire diet offered to them on all days. On average, $84 \%$ of offered $\mathrm{MgSO}_{4}$ diet was consumed, with considerable cow-to-cow variation. All other diets were completely consumed by the cows.

\section{Experiment 2}

Urine $\mathrm{pH}$ and blood $\mathrm{pH}$ and $\mathrm{SBE}$ from the individual trials are summarized in Tables 2 to 4 . Because diet (corn silage vs. alfalfa-based) had no significant effect on the response to the calcium and magnesium salts of chloride and sulfate, these data were combined, and the data from individual trials will not be discussed further. Diet was a significant factor affecting the response to $\mathrm{HCl}$ and $\mathrm{H}_{2} \mathrm{SO}_{4}$. However, these data were also combined as stated in the Materials and Methods. Urine-titratable base data were obtained only in trial 5 examining the effect of $\mathrm{HCl}$ vs. $\mathrm{H}_{2} \mathrm{SO}_{4}$ in cows fed the corn silage-based ration. The amount of added acid 
Table 2. Urine $\mathrm{pH}$ of cows fed alfalfa- or corn silage-based diet with 3 doses of each chloride and sulfate source dissolved in water or water alone (no added anions) added to the diet in trials of experiment 2. (Mean $\pm \mathrm{SEM})(\mathrm{N}=7$ ).

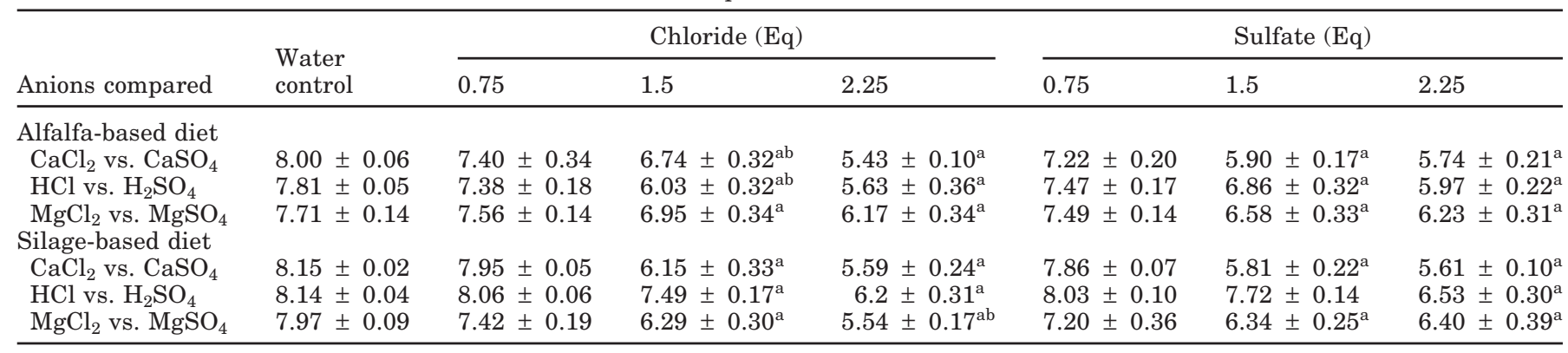

${ }^{a}$ Significantly different from water treatment mean in same trial $(P \leq 0.05)$.

${ }^{\mathrm{b}}$ Significantly different from equivalent amount of sulfate in same trial $(P \leq 0.05)$.

needed to bring urine $\mathrm{pH}$ to 4.5 (titratable base) was $60 \pm 9 \mathrm{~mL}$ during water treatment. There was an incremental decline in the titratable base left in the urine as increasing doses of either $\mathrm{HCl}$ or $\mathrm{H}_{2} \mathrm{SO}_{4}$ were added to the diet (Table 5). There were no significant differences in titratable base content of urine from cows fed equivalent amounts of $\mathrm{HCl}$ and $\mathrm{H}_{2} \mathrm{SO}_{4}$.

\section{Combining Data Across Both Diets: Effect of $\mathrm{CaCl}_{2}$ vs. $\mathrm{CaSO}_{4}$}

Urine $\mathrm{pH}$ of cows fed diet with only water added was $8.08 \pm 0.04$. Urine $\mathrm{pH}$ was significantly reduced by the addition of 1.5 or $2.25 \mathrm{Eq}$ of $\mathrm{CaCl}_{2}$ and by all 3 doses of $\mathrm{CaSO}_{4}$ (Table 6). The urine $\mathrm{pH}$ during treatment with $1.5 \mathrm{Eq} \mathrm{CaSO}_{4}$ was significantly lower than urine $\mathrm{pH}$ during treatment with $1.5 \mathrm{Eq}$ of $\mathrm{CaCl}_{2}$. Blood $\mathrm{pH}$ was significantly reduced from control $(7.44 \pm 0.01)$ only by the addition of $2.25 \mathrm{Eq}$ of $\mathrm{CaCl}_{2}$ and by the addition of 1.5 or $2.25 \mathrm{Eq}$ of $\mathrm{CaSO}_{4}$ (Table 7). Blood $\mathrm{pH}$ during treatment with the $2.25 \mathrm{Eq}$ dose of $\mathrm{CaCl}_{2}$ was significantly lower than the blood $\mathrm{pH}$ observed during treatment with $2.25 \mathrm{Eq}$ of $\mathrm{CaSO}_{4}$. Blood SBE was significantly reduced from control values (5.66 \pm
$0.6 \mathrm{mEq} / \mathrm{L})$ by the 1.5 and $2.25 \mathrm{Eq}$ doses of $\mathrm{CaCl}_{2}$ and $\mathrm{CaSO}_{4}$ (Table 8). Blood SBE during treatment with the $2.25 \mathrm{Eq}$ dose of $\mathrm{CaCl}_{2}$ was significantly lower than the blood SBE observed during treatment with 2.25 $\mathrm{Eq}$ of $\mathrm{CaSO}_{4}$.

\section{Effect of Hydrochloric Acid vs. Sulfuric Acid Across Both Diets}

Urine $\mathrm{pH}$ of cows fed diets with only water added was $7.97 \pm 0.06$. Addition of $0.75 \mathrm{Eq}$ of either $\mathrm{HCl}$ or $\mathrm{H}_{2} \mathrm{SO}_{4}$ was unable to significantly decrease urine $\mathrm{pH}$ from that observed during treatment with only water. Higher doses of $\mathrm{HCl}$ and $\mathrm{H}_{2} \mathrm{SO}_{4}$ did decrease urine $\mathrm{pH}$ significantly. At each equivalent dose of acid added to the diet, the $\mathrm{HCl}$ had a greater acidifying effect on urine $\mathrm{pH}$ than $\mathrm{H}_{2} \mathrm{SO}_{4}$, but this difference was significant only for the $1.5 \mathrm{Eq}$ dose (Table 6). The 1.5 and $2.25 \mathrm{Eq}$ doses of $\mathrm{HCl}$ and $\mathrm{H}_{2} \mathrm{SO}_{4}$ were able to cause a decrease in blood $\mathrm{pH}$ from that observed during water treatment (7.445 \pm 0.003 ) (Table 7). The blood pH during treatment with $2.25 \mathrm{Eq}$ of $\mathrm{HCl}$ was significantly lower than the blood $\mathrm{pH}$ during treatment with 2.25 $\mathrm{Eq}$ of $\mathrm{H}_{2} \mathrm{SO}_{4}$. Similarly, the 1.5 and $2.5 \mathrm{Eq}$ doses of

Table 3. Blood pH of cows fed alfalfa- or corn silage-based diet with 3 doses of each chloride and sulfate source dissolved in water and water alone (no added anions) added to the diet in trials from experiment 2. (Mean $\pm \mathrm{SEM})(\mathrm{N}=7)$.

\begin{tabular}{|c|c|c|c|c|c|c|c|}
\hline Anions compared & $\begin{array}{l}\text { Water } \\
\text { control }\end{array}$ & \multicolumn{3}{|c|}{ Chloride (Eq) } & \multicolumn{3}{|c|}{ Sulfate (Eq) } \\
\hline \multicolumn{8}{|l|}{ Alfalfa-based diet } \\
\hline $\mathrm{HCl}$ vs. $\mathrm{H}_{2} \mathrm{SO}_{4}$ & $7.441 \pm 0.004$ & $7.438 \pm 0.005$ & $7.421 \pm 0.004$ & $7.391 \pm 0.01^{\mathrm{a}}$ & $7.432 \pm 0.009$ & $7.424 \pm 0.009$ & $7.422 \pm 0.008$ \\
\hline $\mathrm{MgCl}_{2}$ vs. $\mathrm{MgSO}_{4}$ & $7.442 \pm 0.014$ & $7.418 \pm 0.008$ & $7.413 \pm 0.008^{\mathrm{a}}$ & $7.386 \pm 0.005^{\mathrm{a}}$ & $7.429 \pm 0.009$ & $7.427 \pm 0.009$ & $7.407 \pm 0.008^{\mathrm{a}}$ \\
\hline \multicolumn{8}{|l|}{ Silage-based diet } \\
\hline $\mathrm{CaCl}_{2}$ vs. $\mathrm{CaSO}_{4}$ & $7.448 \pm 0.009$ & $7.439 \pm 0.005$ & $7.428 \pm 0.005$ & $7.383 \pm 0.010^{\mathrm{ab}}$ & $7.439 \pm 0.007$ & $7.421 \pm 0.004^{\mathrm{a}}$ & $7.419 \pm 0.012^{\mathrm{a}}$ \\
\hline
\end{tabular}

${ }^{\text {a }}$ Significantly different from water treatment mean in same trial $(P \leq 0.05)$.

${ }^{\mathrm{b}}$ Significantly different from equivalent amount of sulfate in same trial $(P \leq 0.05)$. 
Table 4. Standard base excess of blood of cows fed alfalfa- or corn silage-based diet with 3 doses of each chloride and sulfate source dissolved in water and water alone (no added anions) added to the diet in trials of experiment 2. (Mean $\pm \mathrm{SEM})(\mathrm{N}=7)$.

\begin{tabular}{|c|c|c|c|c|c|c|c|}
\hline \multirow[b]{2}{*}{ Anions compared } & \multirow{2}{*}{$\begin{array}{l}\text { Water } \\
\text { control }\end{array}$} & \multicolumn{3}{|c|}{ Chloride (Eq) } & \multicolumn{3}{|c|}{ Sulfate (Eq) } \\
\hline & & 0.75 & 1.5 & 2.25 & 0.75 & 1.5 & 2.25 \\
\hline \multicolumn{8}{|l|}{ Alfalfa-based diet } \\
\hline $\mathrm{HCl}$ vs. $\mathrm{H}_{2} \mathrm{SO}_{4}$ & $6.2 \pm 0.9$ & $4.7 \pm 1.0$ & $2.5 \pm 0.6^{\mathrm{a}}$ & $-0.5 \pm 0.9^{\mathrm{ab}}$ & $4.4 \pm 0.8$ & $3.5 \pm 0.5^{\mathrm{a}}$ & $3.8 \pm 1.0^{\mathrm{a}}$ \\
\hline $\mathrm{MgCl}_{2}$ vs. $\mathrm{MgSO}_{4}$ & $5.5 \pm 2.1$ & $2.8 \pm 0.6$ & $2.5 \pm 0.9$ & $0.2 \pm 0.6^{\mathrm{a}}$ & $5.3 \pm 1.0$ & $3.3 \pm 0.9$ & $2.7 \pm 1.2$ \\
\hline \multicolumn{8}{|l|}{ Silage-based diet } \\
\hline $\mathrm{CaCl}_{2}$ vs. $\mathrm{CaSO}_{4}$ & $6.0 \pm 0.8$ & $5.2 \pm 0.9$ & $3.1 \pm 1.0^{\mathrm{a}}$ & $-1.7 \pm 1.2^{\mathrm{ab}}$ & $3.6 \pm 0.7$ & $3.1 \pm 0.8^{\mathrm{a}}$ & $3.7 \pm 1.5$ \\
\hline
\end{tabular}

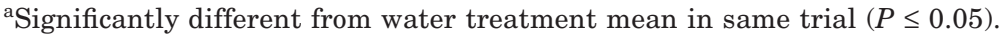

${ }^{\mathrm{b}}$ Significantly different from equivalent amount of sulfate in same trial $(P \leq 0.05)$.

$\mathrm{HCl}$ and $\mathrm{H}_{2} \mathrm{SO}_{4}$ were able to significantly reduce blood SBE from that of water alone $(7.72 \pm 0.72 \mathrm{mEq} / \mathrm{L})$. Blood SBE during treatment with 2.25 Eq of $\mathrm{HCl}$ was significantly lower than blood SBE during treatment with $2.25 \mathrm{Eq}$ of $\mathrm{H}_{2} \mathrm{SO}_{4}$ (Table 8).

\section{Effect of Magnesium Chloride vs. Magnesium Sulfate Across Both Diets}

Urine $\mathrm{pH}$ of cows fed diet with only water added was $7.84 \pm 0.09$. There was no significant urine acidifying effect of $0.75 \mathrm{Eq}$ of either $\mathrm{MgCl}_{2}$ or $\mathrm{MgSO}_{4}$ when compared to water alone. Higher doses of either magnesium salt caused significant decreases in urine $\mathrm{pH}$ (Table 6). Urine $\mathrm{pH}$ during treatment with $2.25 \mathrm{Eq}$ of $\mathrm{MgCl}_{2}$ was lower than urine $\mathrm{pH}$ during treatment with $2.25 \mathrm{Eq}$ of $\mathrm{MgSO}_{4}(P<0.10)$. All 3 doses of $\mathrm{MgCl}_{2}$ were able to cause a decrease in urine $\mathrm{pH}$ from that observed during water treatment $(7.44 \pm 0.01)$ (Table 7). Only the 1.5 and $2.25 \mathrm{Eq}$ doses of $\mathrm{MgSO}_{4}$ were able to significantly decrease blood $\mathrm{pH}$ from that observed during water treatment. The blood $\mathrm{pH}$ during treatment with 1.5 and $2.25 \mathrm{Eq}$ doses of $\mathrm{MgCl}_{2}$ was significantly lower than the blood $\mathrm{pH}$ during treatment with equivalent doses of $\mathrm{MgSO}_{4}$. All 3 doses of $\mathrm{MgCl}_{2}$ were able to significantly reduce blood SBE from that of water alone $(6.00 \pm 1.05 \mathrm{mEq} / \mathrm{L})$. Only the $1.5 \mathrm{Eq}$ dose of $\mathrm{MgSO}_{4}$ caused a significant change in blood $\mathrm{pH}$ from that observed during water treatment (Table 8). Blood SBE during treatment with $2.25 \mathrm{Eq}$ of $\mathrm{MgCl}_{2}$ was significantly lower than blood SBE during treatment with $2.25 \mathrm{Eq}$ of $\mathrm{MgSO}_{4}$.

\section{Combined Effect of Chloride vs. Sulfate Sources Across Both Diets}

The data were also analyzed by combining the 3 chloride source treatments into one treatment and the 3 sulfate source treatments into one treatment. Urine $\mathrm{pH}$, blood $\mathrm{pH}$, and blood SBE values were incrementally reduced as increasing doses of chloride or sulfate were added to the diet (Figure 2). There was no difference in urinary acidifying effect of the chloride and sulfate salts. However, blood $\mathrm{pH}(P<0.002)$ and blood SBE $(P<0.0001)$ were significantly lower when chloride served as the source of anions.

Combining data from the 3 doses of each source of anion and examining the effect of chloride vs. sulfate and water across both diets suggests no difference in urinary acidifying effect between the chloride and sulfate anions (Figure 3). The reduction in blood $\mathrm{pH}$ caused by addition of sulfate anions to the diet was $59 \%$ of that caused by the addition of chloride anions to the diet. The reduction in blood SBE caused by addition of sulfate anions to the diet was $55 \%$ of that caused by the addition of chloride anions to the diet.

Table 5. Urine titratable base of cows fed a corn silage-based diet with 3 doses of either $\mathrm{HCl}$ or $\mathrm{H}_{2} \mathrm{SO} 4$ dissolved in water and water alone (no added anions) added to the diet in trial 5 of experiment 2. (Mean $\pm \mathrm{SEM})(\mathrm{N}=7)$

\begin{tabular}{lllllllll}
\hline & \multirow{2}{*}{$\begin{array}{l}\text { Water } \\
\text { control }\end{array}$} & 0.75 & 1.5 & & \multicolumn{3}{c}{ Sulfate (Eq) } \\
\cline { 3 - 5 } \cline { 7 - 9 } & & 0.25 & & 0.75 & 1.5 & 2.25 \\
\hline Urine titratable base & $60 \pm 9$ & $45 \pm 5^{\mathrm{a}}$ & $20 \pm 3^{\mathrm{a}}$ & $9 \pm 2^{\mathrm{a}}$ & & $42 \pm 4^{\mathrm{a}}$ & $31 \pm 5^{\mathrm{a}}$ & $14 \pm 2^{\mathrm{a}}$ \\
\hline
\end{tabular}

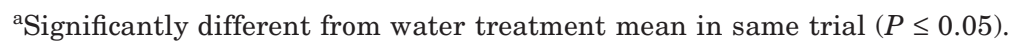


Table 6. Urine $\mathrm{pH}$ of cows given 3 doses of each chloride and sulfate source dissolved in water and water alone (no added anion across both diets of experiment 2 . (Mean $\pm \mathrm{SEM})(\mathrm{N}=14)$

\begin{tabular}{|c|c|c|c|c|c|c|c|}
\hline Anions compared & $\begin{array}{l}\text { Water } \\
\text { control }\end{array}$ & \multicolumn{3}{|c|}{ Chloride (Eq) } & \multicolumn{3}{|c|}{ Sulfate $(\mathrm{Eq})$} \\
\hline & & & & Combined effects & & & \\
\hline
\end{tabular}

a Significantly different from water treatment mean in same trial $(P \leq 0.05)$.

${ }^{\mathrm{b}}$ Significantly different from equivalent amount of sulfate in same trial $(P \leq 0.05)$.

\section{DISCUSSION}

Growing evidence suggests that acid-base status ultimately determines parathyroid hormone responsiveness of tissues and ability to maintain calcium homeostasis (Goff et al., 1991; Phillippo et al., 1994). Therefore, sources of anions that differ in their ability to alter blood $\mathrm{pH}$ or SBE might also differ in their ability to prevent hypocalcemia. Blood SBE, provided plasma protein does not vary, provides an accurate estimate of the acid-base status that is essentially not affected by blood partial pressure of carbon dioxide, i.e., it is a good measure of the nonrespiratory, or metabolic, component of an acid-base disturbance (Constable, 1999). Blood $\mathrm{pH}$, while theoretically less able to discern the effects of diet on metabolic alkalosis and acidosis, is more commonly measured. Urine $\mathrm{pH}$ is easily measured and has proven useful in the field to adjust dietary cation-anion difference (DCAD). However, it does not always accurately assess the degree of acidosis induced by chloride or sulfate addition to the diet. For routine monitoring of the dry cow, the ease with which urine $\mathrm{pH}$ can be measured more than makes up for its inaccuracy.

The difference between the number of cation and anion particles absorbed from the diet determines the $\mathrm{pH}$ of the blood (Stewart, 1983). The cation-anion difference of a diet is commonly described in terms of $\mathrm{mEq} / \mathrm{kg}$ of just sodium, potassium, chloride, and sulfate as follows:

$$
\mathrm{CAD}=\left(\mathrm{Na}^{+}+\mathrm{K}^{+}\right)-\left(\mathrm{Cl}^{-}+\mathrm{S}^{--}\right)
$$

Whereas this equation has proved quite useful, it assigns equal value to chloride and sulfate salts as contributors to DCAD. In the case of the close-up dry cow, we might presume this means that dietary chloride and sulfate anions contribute equally to changes in acid-base status of the cow and, therefore, the parathyroid-hormone sensitivity of her tissues. However, the data from experiments 1 and 2 demonstrate that dietary sulfate anions are less potent acidifiers of the blood than are dietary chloride anions. In experiment 1 , treating with the 2-Eq dose of each chloride source reduced urine $\mathrm{pH}$, blood $\mathrm{pH}$ more than the 2 -Eq dose of the sulfate source. These results were similar to the effects observed in experiment 2 at the 2.25-Eq doses of the various chloride and sulfate sources. However, at the lower anion doses utilized in experiment 2 , the differences between the chloride and sulfate sources on measures of acid-base physiology were small to imperceptible (Figure 2). We speculate that there is some blockade of sulfate absorption at higher doses, while chloride absorption continues unabated. Another possibility is that sulfate is cleared from the blood faster than chloride, especially at higher blood levels. If absorbed sulfate is quickly excreted into the urine or bile, it might not exert as great an effect on blood $\mathrm{pH}$, while continuing to add to the anion content of the urine and therefore decreasing urine $\mathrm{pH}$. The results of this

Table 7. Blood $\mathrm{pH}$ of cows given 3 doses of each chloride and sulfate source dissolved in water and water alone (no added anions) across both diets of experiment 2 . (Mean $\pm \mathrm{SEM})(\mathrm{N}=14)$

\begin{tabular}{|c|c|c|c|c|c|c|c|}
\hline \multirow[b]{2}{*}{ Anions compared } & \multirow{2}{*}{$\begin{array}{l}\text { Water } \\
\text { control }\end{array}$} & \multicolumn{3}{|c|}{ Chloride (Eq) } & \multicolumn{3}{|c|}{ Sulfate (Eq) } \\
\hline & & 0.75 & 1.5 & 2.25 & 0.75 & 1.5 & 2.25 \\
\hline & & & & Combined effects & & & \\
\hline $\mathrm{HCl}$ vs. $\mathrm{H}_{2} \mathrm{SO}_{4}$ & $7.445 \pm 0.003$ & $7.442 \pm 0.003$ & $7.430 \pm 0.005^{\mathrm{a}}$ & $7.402 \pm 0.006^{\mathrm{ab}}$ & $7.436 \pm 0.005$ & $7.431 \pm 0.006^{\mathrm{a}}$ & $7.423 \pm 0.005^{\mathrm{a}}$ \\
\hline $\mathrm{MgCl}_{2}$ vs. $\mathrm{MgSO}_{4}$ & $7.441 \pm 0.007$ & $7.420 \pm 0.004^{\mathrm{a}}$ & $7.405 \pm 0.005^{\mathrm{ab}}$ & $7.392 \pm 0.004^{\mathrm{ab}}$ & $7.431 \pm 0.006$ & $7.422 \pm 0.006^{\mathrm{a}}$ & $7.417 \pm 0.007^{\mathrm{a}}$ \\
\hline
\end{tabular}

a Significantly different from water treatment mean in same trial $(P \leq 0.05)$.

${ }^{\mathrm{b}}$ Significantly different from equivalent amount of sulfate in same trial $(P \leq 0.05)$. 
Table 8. Blood standard base excess of cows given 3 doses each of chloride and sulfate source dissolved in water and water alone (no added anions) across both diets of experiment 2. (Mean $\pm \mathrm{SEM})(\mathrm{N}=14)$

\begin{tabular}{|c|c|c|c|c|c|c|c|}
\hline \multirow[b]{2}{*}{ Anions compared } & \multirow{2}{*}{$\begin{array}{l}\text { Water } \\
\text { control }\end{array}$} & \multicolumn{3}{|c|}{ Chloride (Eq) } & \multicolumn{3}{|c|}{ Sulfate (Eq) } \\
\hline & & 0.75 & 1.5 & 2.25 & 0.75 & 1.5 & 2.25 \\
\hline & \multicolumn{7}{|c|}{ Combined effects } \\
\hline $\mathrm{CaCl}_{2}$ vs. $\mathrm{CaSO}_{4}$ & $5.7 \pm 0.6$ & $5.1 \pm 0.8$ & $3.3 \pm 0.6^{\mathrm{a}}$ & $-1.8 \pm 0.6^{\mathrm{ab}}$ & $5.0 \pm 0.5$ & $2.8 \pm 0.4^{\mathrm{a}}$ & $2.6 \pm 0.9$ \\
\hline $\mathrm{HCl}$ vs. $\mathrm{H}_{2} \mathrm{SO}_{4}$ & $7.7 \pm 0.7$ & $6.4 \pm 0.8$ & $4.1 \pm 0.7^{\mathrm{a}}$ & $1.9 \pm 0.9^{\mathrm{ab}}$ & $6.4 \pm 0.8$ & $5.4 \pm 0.7^{\mathrm{a}}$ & $4.7 \pm 0.7$ \\
\hline $\mathrm{MgCl}_{2}$ vs. $\mathrm{MgSO}_{4}$ & $6.0 \pm 1.1$ & $3.9 \pm 0.5$ & $2.4 \pm 0.6^{\mathrm{a}}$ & $0.1 \pm 0.6^{\mathrm{ab}}$ & $5.7 \pm 1.0$ & $3.4 \pm 0.6^{\mathrm{a}}$ & $4.3 \pm 0.9$ \\
\hline
\end{tabular}

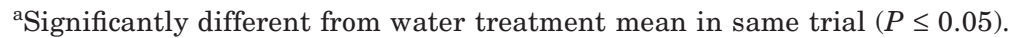

${ }^{\mathrm{b}}$ Significantly different from equivalent amount of sulfate in same trial $(P \leq 0.05)$.

study, demonstrating a difference in acid-base effects between dietary chloride and sulfate, are not unique. Oetzel et al. (1991) screened a number of anionic salts for effects on urine $\mathrm{pH}$ and close examination of their data also demonstrates that the sulfate salts are less able to cause urinary acidification than are chloride salts. Returning to the traditional DCAD equation it might therefore seem appropriate to discount dietary sulfate when comparing it to chloride as a means of affecting blood $\mathrm{pH}$.

It is difficult to determine just how much more potent chloride salts are. Tucker et al. (1991) compared addition of the same number of equivalents of chloride or sulfate into lactating cow diets to achieve similar DCAD [according to the equation DCAD $=(\mathrm{Na}+\mathrm{K})-$ $(\mathrm{Cl}+\mathrm{S})]$ and concluded sulfate was about $60 \%$ as acidifying as chloride. Our data suggest that the acidifying effect of $\mathrm{CaSO}_{4}$ compares favorably with $\mathrm{CaCl}_{2}$ at the same dose, while $\mathrm{MgSO}_{4}$ is a much weaker acidifying agent than $\mathrm{MgCl}_{2}$. However, if we ignore these source effects and look at the grand total effect of chloride vs. sulfate across all anion sources, doses, and diets it would seem that sulfate is between 55 and $60 \%$ as effective as chloride at changing blood $\mathrm{pH}$ and SBE (Figure 3), confirming the work of Tucker et al. (1991). Therefore, the DCAD equation could be more accurately written as $\left(\mathrm{Na}^{+}+\mathrm{K}^{+}\right)-\left(\mathrm{Cl}^{-}+0.6 \mathrm{~S}^{--}\right)$.

This equation may also be considered incomplete as it ignores the contribution other major cations (calcium and magnesium) and anions (phosphorus), present in significant amounts in most diets, can have on DCAD and acid-base status. It is tempting, but wrong, to express DCAD as $\left(\mathrm{Na}^{+}+\mathrm{K}^{+}+\mathrm{Ca}^{++}+\mathrm{Mg}^{++}\right)-\left(\mathrm{Cl}^{-}\right.$ $+0.6 \mathrm{~S}^{--}+\mathrm{P}^{---}$) because this equation assumes that $\mathrm{Ca}$ and $\mathrm{Mg}$ are as strongly alkalinizing as $\mathrm{Na}$ and $\mathrm{K}$ and that $\mathrm{P}$ is as strongly acidifying as $\mathrm{Cl}$. A discount must be applied to these other dietary cations and anions to adjust for their lower absorption (or perhaps retention) and acidifying activity. Unfortunately, experimental data required to assign coefficients to these other variables are lacking. However, in experiment 1 , where many different salts were fed in the same
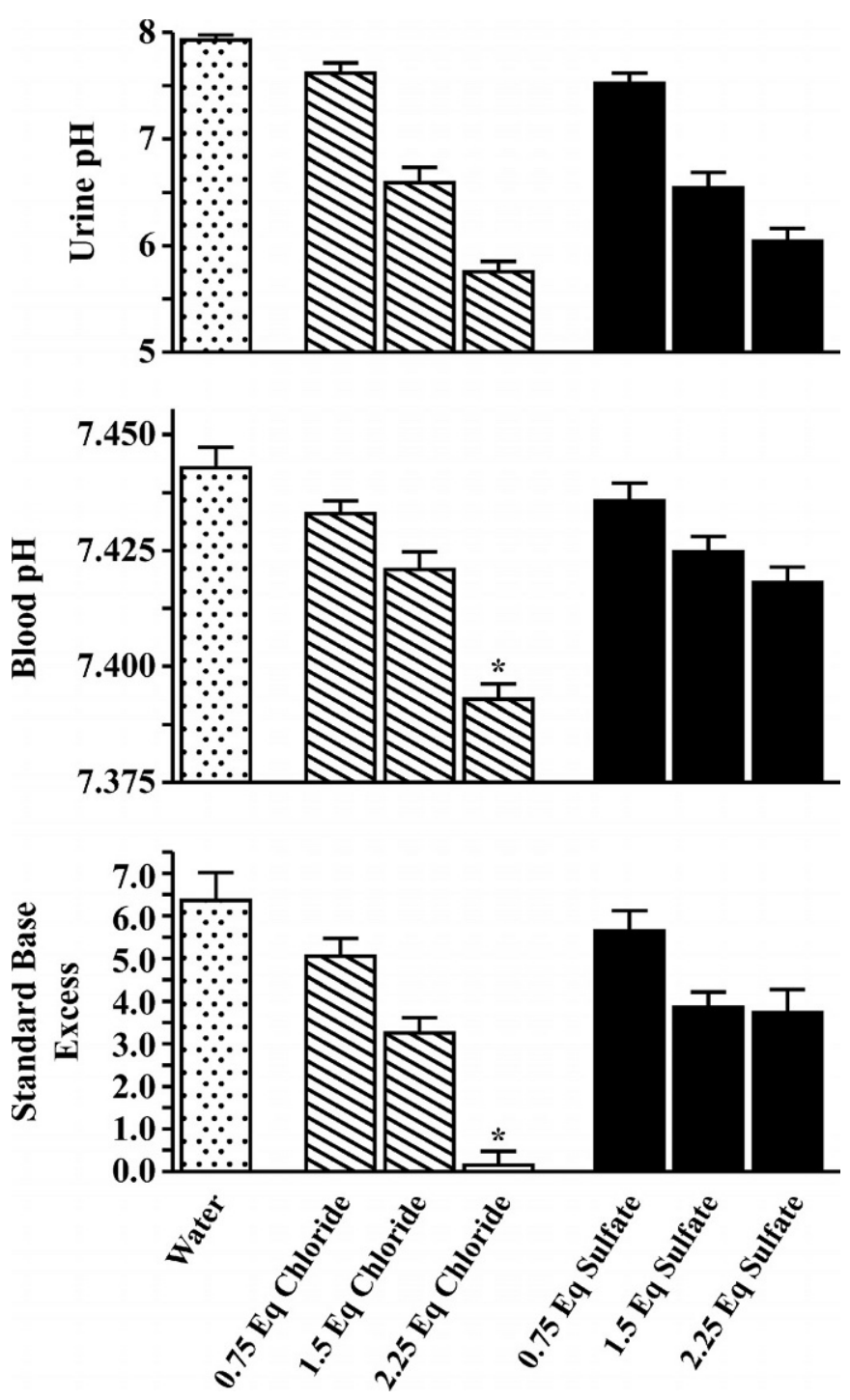

Figure 2. Effect of dose of anion (or no anion supplement = water) supplementation on urine $\mathrm{pH}$, blood $\mathrm{pH}$, and blood standard base excess across all chloride and sulfate sources and across both diets utilized in experiment 2. Mean \pm SEM. Each bar represents 42 observations. *Denotes significantly different from sulfate $(P<0.05)$. 

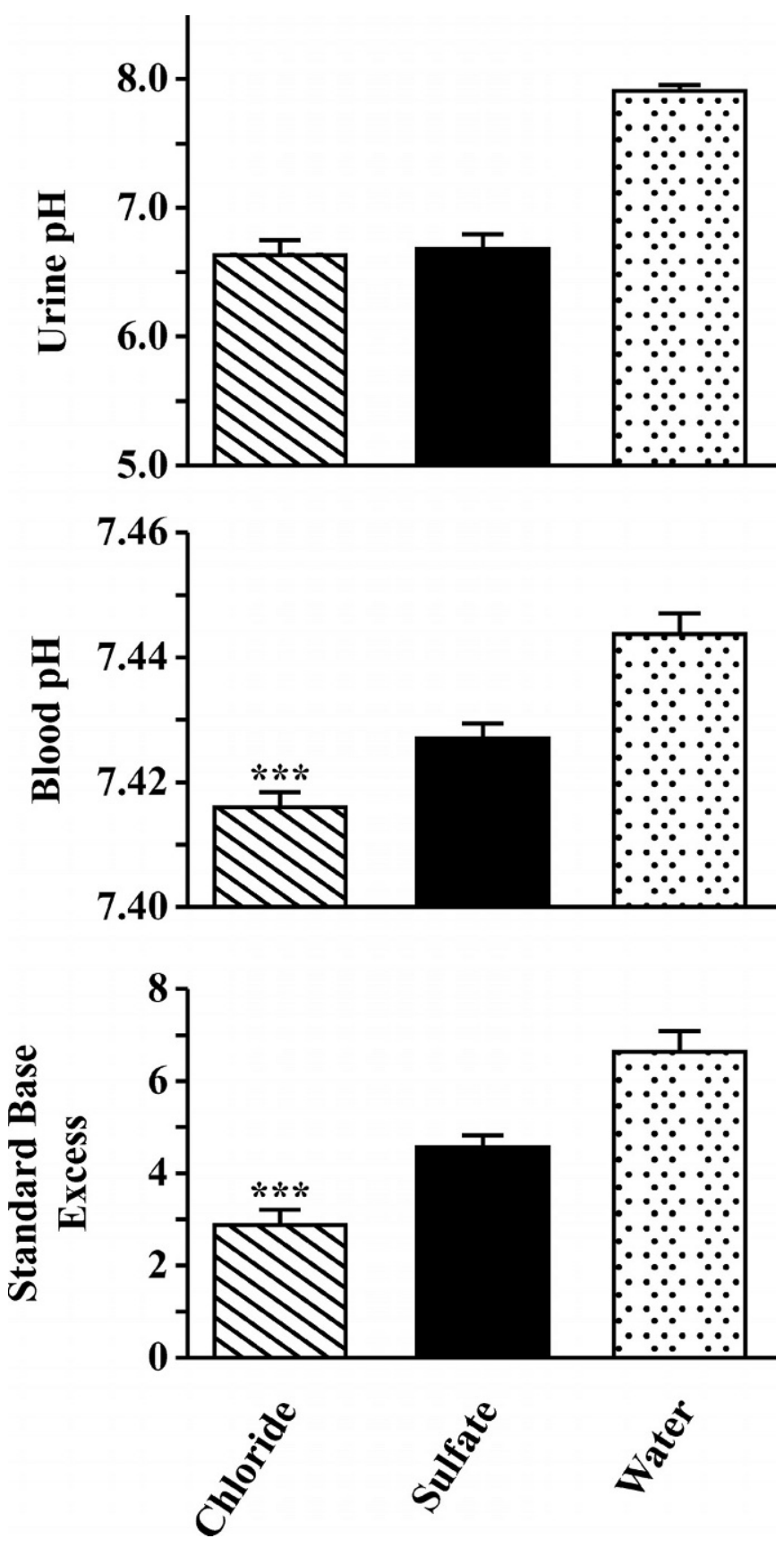

Figure 3. Effect of anion supplementation (or no anion supplement $=$ water) on urine $\mathrm{pH}$, blood $\mathrm{pH}$, and blood standard base excess across all 3 anion doses, all chloride and sulfate sources, and both diets utilized in experiment 2 . Mean \pm SEM. The chloride and sulfate bars represent 126 observations and the water bar represents 42 observations. *** Denotes significantly different from sulfate $(P<0.05)$.

trial, feeding $\mathrm{CaSO}_{4}$ or $\mathrm{MgSO}_{4}$ did reduce urine $\mathrm{pH}$. It can therefore be assumed that the urine alkalinizing activity of calcium and magnesium cations is less than the acidifying activity of sulfate anions. Fewer dietary cations than anions were absorbed into the blood. Therefore, the DCAD equation coefficients for calcium and magnesium must be less than 0.6. Because urine $\mathrm{pH}$ of cows fed $\mathrm{CaCl}_{2}$ or $\mathrm{NH}_{4} \mathrm{Cl}$ was higher than urine $\mathrm{pH}$ of cows fed $\mathrm{HCl}$, it is clear that the calcium and ammonium cations are contributing some alkalinity to the blood. At least some of these cations are being absorbed into the blood, and therefore the coefficient applied to these cations (as well as magnesium) in the equation should be greater than zero. In the traditional DCAD equation, there is no allowance made for the effect the ammonium cation could have on DCAD. However, it is clear from experiment 1 that $\mathrm{NH}_{4} \mathrm{Cl}$ did not acidify urine as strongly as did $\mathrm{HCl}$. As with the work of Oetzel et al. (1991), $\mathrm{CaCl}_{2}$ and $\mathrm{NH}_{4} \mathrm{Cl}$ were nearly equipotent as urinary acidifiers. Just as with calcium and magnesium, ammonium should be included in the DCAD equation.

When cows received the water only added to their diet, all were producing alkaline urine. Their blood SBE was highly positive, consistent with observations that cows are normally in a state of compensated metabolic alkalosis. When placed on the highest doses of anions, all cows exhibited a decrease in blood SBE and urine $\mathrm{pH}$ while blood $\mathrm{pH}$ dropped only slightly. Larger total anion loads or more negative DCAD diets could have placed these cows in a state of uncompensated metabolic acidosis. The cows in this study (with the exception of those fed magnesium sulfate) continued to consume their entire ration, suggesting they had not entered a state of uncompensated metabolic acidosis. The cows were able to achieve a state of compensated metabolic acidosis with the doses of anion used in these studies.

The diet the cows were fed had little effect on the response of the cows to the anion supplementation. Whether potassium was from endogenous plant sources or from potassium carbonate mineral source did not seem to have an effect on the relative response to anions. No great interactions between basal diet protein, diet calcium, or diet magnesium content and anion supplementation were observed. Our goal in setting up the 2 diets was to try to determine the effects of a high nitrogen diet (which might be expected to result in ammonium cation production) on acid-base balance. Unfortunately any effect of NPN in the alfalfa diet was overwhelmed by the addition of potassium to the corn silage (low nitrogen) diet.

In some cases, the DCAD equations have been interpreted to suggest that elemental sulfur is equivalent to the sulfate anion. Results of experiment 1 demonstrate this interpretation is clearly wrong, as elemental sulfur is not capable of acidifying the urine. 
Sulfur and sulfate are potentially toxic because they can be reduced to hydrogen sulfide in the rumen, a potent neurotoxin (Gould et al., 1991). Therefore the amount of sulfate added to the diet must be limited. The current maximum tolerable limit for dietary sulfur in cattle is thought to be $0.4 \%$ of the diet DM (National Research Council, 2001). Because low doses of sulfate coming from $\mathrm{CaSO}_{4}$ and $\mathrm{H}_{2} \mathrm{SO}_{4}$ appear to be equipotent to low doses of chloride sources, adding small amounts of these salts would be useful—so long as inclusion does not bring total sulfur content above $0.4 \%$. Reagent grade concentrated $\mathrm{H}_{2} \mathrm{SO}_{4}$ is between 95 and $98 \%$ pure, while reagent grade $\mathrm{HCl}$ is just 36.5 to $38 \% \mathrm{HCl}$ by weight. Thus the volume of $\mathrm{H}_{2} \mathrm{SO}_{4}$ required to add $1 \mathrm{Eq}$ anion to the diet would be very low; there is $1 \mathrm{Eq}$ of anion/ $28 \mathrm{~mL}$ of concentrated $\mathrm{H}_{2} \mathrm{SO}_{4}$, while reagent grade $\mathrm{HCl}$ supplies $1 \mathrm{Eq}$ of anion/83 mL.

In experiment 1 of this study, $\mathrm{MgSO}_{4}$ was the only anion not totally consumed by the cows. In experiment 2 , all anions added to the rations were consumed, though it was observed that the diet with magnesium sulfate was consumed more slowly. These observations raise questions about the commonly held belief that sulfate salts, particularly magnesium sulfate, are more palatable than chloride salts.

Several of the variables in the above formulas are somewhat fixed when balancing rations. If diet $\mathrm{Ca}$ is set at $1 \%, \mathrm{P}$ at $0.35 \%, \mathrm{Mg}$ at $0.4 \%$, and sulfur at $0.35 \%$ (above $0.22 \%$ to ensure adequate substrate for rumen microbial amino acid synthesis, but below $0.4 \%$ to avoid possible neurological problems associated with sulfur toxicity [Gould et al., 1991]), the only real variables in the equation become $\mathrm{Na}, \mathrm{K}$, and $\mathrm{Cl}$. The goal for milk fever prevention is to keep sodium and potassium as close to the requirement of the cow as possible ( $\sim 0.12 \%$ for $\mathrm{Na}$ and $\sim 1.0 \%$ for potassium). The key to reduction of hypocalcemia is to then add chloride to the ration to counteract the effects of even low levels of potassium on blood alkalinity.

\section{CONCLUSIONS}

Assuming acidification of the blood of the prepartal cow allows the cow to achieve calcium homeostasis at the onset of lactation, the addition of chloride to prepartal diets would prove more effective than sulfate because sulfate has about $60 \%$ of the blood acidifying activity of chloride. This is especially apparent at the higher doses of anion required to successfully overcome the metabolic alkalosis observed in the prepartum cow on a typical ration. Interestingly, when included in the ration in lower amounts, sulfate from $\mathrm{CaSO}_{4}$ and $\mathrm{H}_{2} \mathrm{SO}_{4}$ proved as strongly acidifying as chloride from $\mathrm{CaCl}_{2}$ or $\mathrm{HCl}$. $\mathrm{MgSO}_{4}$ was much less acidifying than $\mathrm{MgCl}_{2}$ at all doses tested. It appears that there is some blockade to sulfate absorption or acidifying action at higher doses. Though $\mathrm{MgSO}_{4}$ is commonly used as an anion to prevent milk fever, these data discourage the use of $\mathrm{MgSO}_{4}$ as an acidifying agent, though it may still prove a good source of magnesium. The intestinal absorption of accompanying cations such as calcium, magnesium, and ammonium in an anionic salt can counteract the acidifying effect of the absorbed chloride or sulfate anion of that salt and, although these cations are not considered in the common DCAD equations, they may need to be considered when formulating dry cow rations. Though monitoring urine $\mathrm{pH}$ has proven useful in the field as a means of monitoring the acidification of the blood caused by anion supplementation, it is not foolproof. Sulfate salts were able to acidify the urine to the same extent as the chloride salts but were not acidifying the blood to the same extent.

\section{ACKNOWLEDGMENTS}

The authors would like to thank Norm Tjelmeland, Creig Caruth, and Bruce Grey for their diligent care of the cows on these experiments; Cynthia Hauber, Andrea Steffens, and Douglas Mashek for their excellent technical assistance in completion of these studies and Annette Bates for preparation of the manuscript.

\section{REFERENCES}

Block, E. 1984. Manipulating dietary anions and cations for prepartum dairy cows to reduce incidence of milk fever. J. Dairy Sci. 67:2939-2948.

Bushinsky, D. A. 1996. Metabolic alkalosis decreases bone calcium efflux by suppressing osteoclasts and stimulating osteoblasts. Am. J. Physiol. 271:F216-F222.

Constable, P. D. 1999. Clinical assessment of acid-base status. Strong ion difference theory. Vet Clin. North Am Food Anim. Pract. 15:447-471.

Davidson, J., L. Rodriguez, T. Pilbeam, and D. Beede. 1995. Urine pH check helps avoid milk fever. Hoard's Dairyman 140:634.

Dishington, I. W. 1975. Prevention of milk fever (hypocalcemic paresis puerperalis) by dietary salt supplements. Acta Vet. Scand. 16:503-512.

Ender, F., I. W. Dishington, and A. Helgebostad. 1971. Calcium balance studies in dairy cows under experimental induction and prevention of hypocalcaemic paresis puerperalis. The solution of the aetiology and the prevention of milk fever by dietary means. Z. Tierphysiol. Tierernahr. Futtermittelkd. 28:233-256.

Gaynor, P. J., F. J. Mueller, J. K. Miller, N. Ramsey, J. P. Goff, and R. L. Horst. 1989. Parturient hypocalcemia in Jersey cows fed alfalfa haylage-based diets with different cation to anion ratios. J. Dairy Sci. 72:2525-2531.

Goff, J. P., and R. L. Horst. 1997. Effects of the addition of potassium or sodium, but not calcium, to prepartum rations on milk fever in dairy cows. J. Dairy Sci. 80:176-186.

Goff, J. P., and R. L. Horst. 1998 Use of hydrochloric acid as a source of anions for prevention of milk fever. J Dairy Sci. 1998 81:2874-2880.

Goff, J. P., R. L. Horst, F. J. Mueller, J. K. Miller, G. A. Kiess, and H. H. Dowlen. 1991. Addition of chloride to a prepartal diet 
high in cations increases 1,25 -dihydroxyvitamin $\mathrm{D}$ response to hypocalcemia preventing milk fever. J. Dairy Sci. 74:3863-3871.

Goff, J. P., T. A. Reinhardt, and R. L. Horst. 1989. Recurring hypocalcemia of bovine parturient paresis is associated with failure to produce 1,25-dihydroxyvitamin D. Endocrinology 125:49-53.

Gould, D. H., M. M. McAllister, J. C. Savage, and D.W. Hamar. 1991. High sulfide concentrations in rumen fluid associated with nutritionally induced polioencephalomalacia in calves. Am. J. Vet. Res. 52:1164-1169.

Jardon, P. W. 1995. Using urine $\mathrm{pH}$ to monitor anionic salt programs. Compend. Contin. Educ. Pract. Vet. 17:860-866.

National Research Council. 2001. Pages 131-132 in Nutrient Requirements of Dairy Cattle. 7th Revised Edition, National Academy Press, Washington, DC.

Oetzel, G. R., J. D. Olson, C. R. Curtis, and M. J. Fettman. 1988. Ammonium chloride and ammonium sulfate for prevention of parturient paresis in dairy cows. J. Dairy Sci. 71:3302-3309.
Oetzel, G. R., M. J. Fettman, D. W. Hamar, and J. D. Olson. 1991. Screening of anionic salts for palatability, effects on acid-base status and urinary calcium excretion in dairy cows. J. Dairy Sci. 74:965-971.

Phillippo, M., G. W. Reid, and I. M. Nevison. 1994. Parturient hypocalcaemia in dairy cows: Effects of dietary acidity on plasma minerals and calciotrophic hormones. Res. Vet. Sci. 56:303-309.

Stewart, P. A. 1983. Modern quantitative acid-base chemistry. Can. J. Physiol. Pharmacol. 61:1444-1461.

Thomas, L. J. 1972. Algorithms for selected blood acid-base and blood gas calculations. J Appl. Physiol. 3:154-158.

Tucker, W. B., J. F. Hogue, D. F. Waterman, T. S. Swenson, Z. Xin, R. W. Hemken, J. A. Jackson, G. D. Adams, and L. J. Spicer. 1991. Role of sulfur and chloride in the dietary cation-anion balance equation for lactating dairy cattle. J. Anim. Sci. 69:1205-1213. 